\title{
JUGUN IANFU IN LITERARY WORKS: A FEMICIDE READING
}

\section{(Jugun Ianfu dalam Karya Sastera: Satu Bacaan Femisid)}

\author{
Nor Atikah Zaki \\ noratikahzaki82@gmail.com
}

Siti Hajar Che Man

shajar@usm.my

School of Humanities, Universiti Sains Malaysia.

Published online: 9 June 2020

To Cite: Nor Atikah Zaki and Siti Hajar Che Man. (2020). Jugun Ianfu in Literary Works: A Femicide Reading. Malay Literature, 33(1), 45-66.

\begin{abstract}
The field of Literature presents life stories, either explicitly or implicitly. Human life is depicted in literary works unconstrained by time and place. This paper attempts to recollect how women became victims of war crimes during the outbreak of the Second World War, whose impact is felt until now. They were victimized solely because they were women, forced to become sex slaves, raped, tortured and even murdered. The discussion focuses on novels, namely Perawan Remaja dalam Cengkeraman Militer [Virgin Girls in the Grip of the Military] (2001) by Pramoedya Ananta Toer and Cantik Itu Luka [Beauty is a Wound] (2004) by Eka Kurniawan. The analysis of the study will use the femicide reading pioneered by Russell. This method will show the "killing of females by males because they are females" through the sexual exploitation of women as jugun ianfu or "comfort women". The fact is, these were women and girls who were forced to become sex slaves. This very tragic war crime has left a deep mark, and literary works that successfully portray itare historical and cultural documents for future generations to ponder and react to.
\end{abstract}

Keywords: Femicide, war crimes, jugun ianfu, sexuality, literature 


\begin{abstract}
Abstrak
Bidang Ilmu Kesusasteraan menawarkan pelbagai kerencaman tentang kehidupan sama ada terpancar secara tersurat mahupun tersirat. Fenomena kehidupan manusia menerusi karya kesusasteraan tidak terbatas waktu dan tempat. Menerusi makalah ini, satu perbincangan cuba mengimbau kembali golongan wanita yang menjadi mangsa jenayah perang ketika meletusnya perang dunia kedua dan kesannya hingga kini terasa. Golongan ini teraniaya kerana mereka perempuan, menjadi hamba seks kepada tentera lelaki tanpa rela, diperkosa, diseksa bahkan dibunuh. Tumpuan perbincangan memfokuskan kepada genre novel antaranya Perempuan Remaja dalam Cengkeraman Militer (2001) karya Pramoedya Ananta Toer dan Cantik Itu Luka (2004) karya Eka Kurniawan. Analisis kajian akan menggunakan bacaan femicide yang dipelopori oleh Russell. Kaedah ini juga akan memperlihatkan bagaimana "the killing of females by males because there are females" merupakan eksploitasi seksual terhadap wanita yang disebut sebagai jugun ianfu atau comfort women. Hakikatnya, golongan ini adalah wanita dan gadis remaja yang dipaksa menjadi hamba seks. Situasi ini telah meninggalkan kesan jenayah perang yang penuh tragis dan karya sastera telah berjaya memaparkan peristiwa ini sebagai satu dokumen sejarah dan budaya untuk tatapan dan tindakan generasi yang akan datang.
\end{abstract}

Kata kunci: Femisid, jenayah perang, jugun ianfu, seksualiti, sastera

\title{
INTRODUCTION
}

On 7 December 1941, the world was jolted by Japanese attacks on the American naval base in Pearl Harbour (Esguerra, 2009, p. 291). America's defeat in the Pacific, through this surprise attack, gave Japan the opportunity to focus fully on its mission of expanding its empire. Hong Kong, Malaya, Singapore, Borneo, the Philippines and Indonesia were the initial targets of the Japanese mission to establish the Greater East Asia Co-Prosperity Sphere (Mark, 2018; p. 2).

The Dutch, who had already gained a foothold in Indonesia, became one of Japan's main targets since their colonies were rich with spices, oil, rubber and other natural resources. On 11 January 1942, the Japanese army, led by General Imamura, landed on Sulawesi. From there, they invaded other islands, such as Sumatra, Java and Bali. The Dutch army under General Hein 
Ter Poorten surrendered unconditionally on 8 March 1942 (Post, Frederick, Heidebrink, et al., 2010, pp. xvii-xviii).

In general, the Second World War had a huge economic, political and social impact. Politically, it resulted in the the setting up of the United Nations (UN), decolonization, the Cold War, the division of Germany, and the re-delineation of European borders. In terms of the economy, there was massive destruction of agricultural land and industrial areas, loss of lives and the high cost of war reparations. Socially, it resulted in a changed role for women, a refugee problem, and war crime trials. The problem of a reduced labour force in the industrial and manufacturing sectors forced women to become factory workers (https://courses.lumenlearning.com/ boundless-worldhistory/chapter/impact-of-war-world-ii/).

Specifically, however, Dutch rule followed by Japanese occupation brought ever more suffering to the local populace. The occupation of Indonesia by foreign powers were a nightmare for the girls who were forced to become "comfort women" to satisfy the sexual desire of soldiers. Although the effects are still felt by these victims, the international community has not come to their defence. This state of affairs that has been acknowledged by Donald Greenlees who also estimates that there were about 200000 women forced to become labourers, and that at least half that number perished as a result of the war (https://www.nytimes.com/2005/08/15/world/ asia/occupation-helped-put-indonesia-on-the-path-to-independence.html):

Indonesia also suffered during the occupation, if not to the same degree as China or Korea. There is no accurate record of the number of women forced into sex slavery - to be so-called comfort womenbut it is thought to be in the thousands. Historians estimate that there were at least 200,000 forced laborers, or Romusha, more than half of whom died. Periodic uprisings were brutally suppressed.

However, the matter was not entirely swept aside. Sympathizing fully with their plight, Indonesian writers began to focus attention on the stories of these women. They recorded for posterity the horrifying and bitter experiences $\mathrm{n}$ their literary works, such as in the novels Perawan Remaja dalam Cengkeraman Militer [Young Virgins in the Grip of the Military] (2001) by Pramoedya Ananta Toer and Cantik Itu Luka [Beauty is a Wound] by Eka Kurniawan (2004). 


\section{WOMEN AND WAR}

According to the United Nations Declaration of Human Rights (2015, pp.737), cruelty against women happens throughout the world in all communities and countries, regardless of status. In fact, the victimization of women often takes place in smaller groups, such as being based on nationality, religion, race and the like.

The United Nations Declaration on the Elimination of Violence Against Women defines violence against women as:

any act of gender-based violence against women resulting in, or is likely to result in, physical, sexual or psychological harm or suffering to women, including threats of such acts, coercion or arbitrary deprivations of liberty, whether occurring in public or private life.

This shows that the United Nation takes the view that cruelty towards women includes all aspects, including physical, sexual and psychological harm. Political, racial and religious issues involve a country's leadership. However, it is the women who become the victims of the resulting abuse. For instance, the conflict in Myanmar involving ethnic Rohingyas has resulted in the rape and slaughter of their womenfolk. Amnesty International revealed this in a report entitled: "Myanmar: The Institutions of Torture":

Men, women, and children also face torture when they are taken by the Myanmar Army and forced to carry heavy supplies as porters for days or weeks at a time or forced to work on construction projects such as roads, railways, and dams. Women who are taken as porters are vulnerable to rape by soldiers. Amnesty International was told about the rape and murder of a 12-year-old girl, Naw Po Thu in October 1998. She was allegedly raped by a major and managed to escape, but was recaptured, raped again and then shot dead through the vagina. The major gave the girl's family one sack of rice, a measure of sugar, a tin of condensed milk and a small amount of money as compensation.

(Skidmore, 2003, pp. 80-81)

This report clearly shows how women are subjected to rape by the military, regardless of the age of the victim. On the same note, Sabyasachi Basu Ray Chaudhury and Ranabir Samaddar add (2018, p. 55): 
Women are victims of double discrimination - for being Rohingya and for being women. The rape of Rohingya women - even those who are pregnant-is common in Arakan, and Rohingya men are powerless to protest. Women are also abducted. Some are released, and some never return. Pregnant women can be murdered in hospitals, so they deliver at home. Those very near delivery are often attacked and eviscerated.

Based on the statements by these prominent figures, there is clear acknowledgement that women are doubly discriminated: because of their ethnicity as Rohingya, and, at the same time, because they are women. They do not only face discrimination but in some unfortunate cases, the girls are carried off and raped by Myanmar soldiers. Even sadder still, if pregnant women seek treatment the hospital, they could be killed. Men, women and children are subjected to all kinds of torture when they are caught by Myanmar's army, and forced to work on infrastructure projects such as roads, railways and dams.

Similar incidents have taken place in Iraq, where women were tortured and raped by American soldier in inhuman ways (Hassan, 2004). This is supported by a report that states that Iraqi women, in particular, lost their political, economic and in the social freedom since the beginning of the war. In fact they were often victims of violence perpetrated by soldiers who used these women to satisfy their sexual desires. A report by the United Nations in 2013 states:

According to the UN (2013), years of economic sanctions imposed on Iraq and of armed conflict in the country have led to a deteriorating quality of life for women in Iraq. Women are financially, socially and politically marginalised. Women suffer from a lack of education opportunities, insufficient health care, restricted access to the labour market, violence and inequality. The situation is often exacerbated by misunderstandings rooted in traditional, cultural and social values, by a lack of awareness of women's rights and abilities, and by structural and legal obstacles. According to Human Rights Watch (HRW) (2003), the women of Iraq used to enjoy more extensive rights than women elsewhere in the Middle East, but since the Gulf War of 1991 the situation has rapidly declined.

(https://migri.fi/documents/5202425/5914056/Report_Women_Iraq Migri_CIS.pdf/ab7712ba-bad7-4a1f-8c1f-f3f4013428a7/Report_ Women_Iraq_Migri_CIS.pdf). 


\section{DEFINITION AND CONCEPT OF JUGUN IANFU}

The practice of turning girls into jugun ianfu or "comfort women" is one of the dark chapters of the Japanese occupation in the Second World War. Although the occupation ended, the painful history of the girls who became comfort women has persisted. The term "comfort women" refers to the girls who entertained the Japanese army during their occupation of several colonies, such as Indonesia. The reality is that they were not entertainers. On the other hand they were sex slaves - a fact which the international community now recognizes as a war crime (Argibay, 2003, pp. 381-382).

Jugun ianfu (comfort women) generally came from poor families. They were promised scholarships and work opportunities. What actually transpired was they became tools to fulfil the sexual needs of the soldiers. They experienced prolonged suffering because as a result of Japanese army brutality, they became barren and at the same time had to deal with the great burden of moral disgrace. Therefore, they continued to hide their bitter past as it was a great shame to have been a "comfort women". This is acknowledged by Swee Lian (2008, pp. 2-3) in the following excerpt:

When World War II ended with the surrender of Japan in August 1945 , large numbers of these women were found thousands of miles from their homes and in poor mental and physical health, the result of sexual abuse, beatings by their captors and starvation.

War crimes investigators had said young women, especially those from many poor areas in Japanese-occupied territories, were deceived by offers of work as "waitresses in army-run canteens". Some were "recruited" by force or kidnapped and sent to army-brothels.

Following Japan's surrender, evidence was recorded from "sex slaves" who in most cases wished their identities to be kept secret because of the shame they and their families would suffer by being witnesses in War Crimes trials of Japanese war criminals.

Later however, there were efforts to begin revealing the truth and demand that Japan be responsible for the immoral acts of its army during war time. These began in 1991 when Kim Hak-sun, a "comfort women" from Korea, opened up about the atrocities they suffered during the Japanese Occupation. After this initial statement by Kim, South Korea and other countries in East Asia began, one by one, to investigate the issue of 'comfort women'. The victims then laid out their demands to the Tokyo District Court, on 6 
December 1991 (Kumagai, 2016; pp. 6-7) regarding their rights in this matter.

During the Second World War, numerous war crimes were committed, both against civilians and the military. The leaders involved in the war at the time justified their criminal acts as being consistent with the policies that had been set (Argibay, 2003, p. 381). Nevertheless, most of the perpetrators of these crimes were arrested and received due punishment when the war ended. But, when it came to the issue of Japanese army's sex slaves, the jugun ianfu, it evoked debate and remains a polemic right up to the present time.

Many researchers, among them, George Hicks (1995) and Huie (1992) came to the conclusion that the creation of "comfort women" can be considered a war crime based on these justifications:

(1) They did not willingly supply or provide comfort, or sexual gratification to Japanese soldiers.

(2) The bitter experience during the time they were comfort women and after they were liberated caused permanent scarring. Some of them became barren as a result of brutal rape. Some developed continuous headaches, asthma, insomnia, phobias and trauma (nervous breakdowns) due to their horrifying experiences. There were those who avoided meeting family members as they were ashamed of what had happened to them. Some even committed suicide.

(3) For some who became pregnant, they were given STD \#606 (asyphilis drug). This drug caused their body to swell and resulted in miscarriage. In more unfortunate cases, when the girl became pregnant, soldiers would sit on her stomach as many times as needed to push the baby out, after which the baby would then be killed, oftentimes with the mother as well. If the girl carried the baby to term, she would put the baby with its umbilical cord uncut into a sack, which was then tied up and disposed of. The girl was not given time to heal as she had to continue having sexual relations as soon as she had given birth.

This crime which should have been punished 73 years ago seems unresolved, and is a huge insult to all Asian countries involved, including Indonesia. This bitter truth is consistent with the concept of femicide the "killing of females by males because they are female" (2001, p. 13) introduced 
by Russell. In this case, it is the sexual exploitation of women known as "comfort women". The discussion will focus on the acts of cruelty perpetrated against women by men during wartime in Indonesia, based on two texts, Pramoedya Ananta Toer's Perawan Remaja dalam Cengkeraman Militer [Young Virgins in the Grip of the Military] (2001) and Eka Kurniawan's Cantik Itu Luka [Beauty is a Wound] (2004).

\section{DEFINITION AND CONCEPT OF FEMICIDE}

The first documented use of the term femicide dates back to the beginning of the 19th century, where it appearedin the book A Satirical View of London by Corry. Here, it was used in reference to the murder of a woman. However, in 1976 the term was reintroduced by Russell at the International Tribunal for Crimes against Women in order to bring attention to the violence and discrimination towards women (2001, p. 14).

The accepted term and definition often varies. As a result, the phenomenon of femicide, its scope, content and implications are continually subjected to discussions at the international level in academia, among policy-makers and grassroots activists, as well as in the process of regional legislation. At the international level, a broader definition of femicide is often used to include the killing of women as well as female children. The Secretary-General of the United Nations, in his latest report regarding advances towards Sustainable Development, stated that such violence has continued and persisted through the more widespread system of patriarchal oppression, and the ongoing gender inequality. According to the World Health Organization (WHO) (2012, p. 1):

Femicide is generally understood to involve intentional murder of women because they are women, but broader definitions include any killings of women or girls.

This information sheet focuses on the narrower definition commonly used in policies, laws and research: intentional murder of women. Femicide is usually perpetrated by men, but sometimes female family members may be involved.

Femicide differs from male homicide in specific ways. For example, most cases of femicide are committed by partners or ex-partners, and involve ongoing abuse in the home, threats or intimidation, 
sexual violence or situations where women have less power or fewer resources than their partner

(http://apps.who.int/iris/bitstream/handle/10665/77421/WHO RHR_12.38_eg.

This statement by the WHO sums up femicide as a crime that is intentional, with women as the victims. Generally, the torture and murder of women takes place in areas/places that adhere to a patriarchal system. As a result, the victims will find it hard to seek protection. Meanwhile Russell through her book Femicide in Global Perspective (2001, p. 4), is of the view that:

Femicide is on the extreme end of a continuum of the sexist terrorization of women and girls. Rape, torture, mutilation, sexual slavery, incestuous and extra familial child sexual abuse, physical and emotional battery, and serious cases of sexual harassment are also on this continuum. Whenever these forms of sexist terrorism result in death, they become femicides.

Based on this point of view, it is clear that the acts of rape, physical and mental torture that impair health and cause death are part of the concept of femicide introduced by Russell. While The Oxford English Dictionary defines femicide as "the killing of woman" (2001, p. 14), Russell defines femicide as "the killing of females by males because they are female" (2001, p. 13). Through this definition, it can be concluded that where femicide is concerned, women are the victims of men. In order to clarify this matter, Russell divides femicide crimes into three main categories:

In Table 1, the first category is "Female Acting as Agent of Patriarchy" which is a form of marital abuse of women. This involves cases whereby mothers-in-law or female relatives behave cruelly towards the victim or female infant she gives birth to, through abuse or simply letting the infant starve. The menfolk may also be involved in aiding the female relatives commit these abusive acts.

The second category, "Female Acting as Agent of Male Perpetrators", includes cases whereby women become sex slaves and victims of torture by men. Such abuse may cause injury and death. At the same time, consistent with the definition given by Russell, "killing of females by males because 
Table 1 Modified typology of female-perpetrated femicide based on the views of Russell \& Harmes (2001, p.17).

\begin{tabular}{|c|c|c|}
\hline $\begin{array}{l}\text { Female Acting as } \\
\text { Agent of Patriarchy }\end{array}$ & $\begin{array}{l}\text { Female Acting as } \\
\text { Agent of Male } \\
\text { Perpetrators }\end{array}$ & $\begin{array}{c}\text { Female Acting on Own } \\
\text { Behalf }\end{array}$ \\
\hline $\begin{array}{l}\text { Killings involving } \\
\text { Dowry Example: } \\
\text { Mother-in-law who } \\
\text { kills daughter-in-law or } \\
\text { assists male relative in } \\
\text { the killing }\end{array}$ & $\begin{array}{l}\text { Sexual slavery where } \\
\text { wife/partner assists } \\
\text { husband/partner to } \\
\text { commit femicide } \\
\text { Wife is forced to assist } \\
\text { husband in killing } \\
\text { female child } \\
\text { Killing of females in } \\
\text { groups }\end{array}$ & $\begin{array}{l}\text { Killing committed out } \\
\text { of jealousy } \\
\text { Example: Killing } \\
\text { of mother-in-law, } \\
\text { husband's lover, } \\
\text { lesbian partner }\end{array}$ \\
\hline $\begin{array}{l}\text { Killing of female child } \\
\text { Example: mother kills } \\
\text { female child through } \\
\text { act of neglect, letting } \\
\text { child starve }\end{array}$ & $\begin{array}{l}\text { Females who feel proud } \\
\text { having assisted males } \\
\text { kill other females }\end{array}$ & $\begin{array}{l}\text { Killing because of } \\
\text { money, greed } \\
\text { Example: killing of } \\
\text { mother, relatives, rich } \\
\text { employer }\end{array}$ \\
\hline $\begin{array}{l}\text { Genital mutilation-- } \\
\text { death that occurs } \\
\text { because of } \\
\text { carelessness/ } \\
\text { complications }\end{array}$ & $\begin{array}{l}\text { Females who are } \\
\text { pressured to commit } \\
\text { suicide due to abuse by } \\
\text { husband, father, son, } \\
\text { male friend }\end{array}$ & $\begin{array}{l}\text { Females who commit } \\
\text { suicide due to abuse by } \\
\text { other females } \\
\text { Example: mother }\end{array}$ \\
\hline - & - & $\begin{array}{l}\text { Killing because of } \\
\text { uncontrollable anger }\end{array}$ \\
\hline - & & $\begin{array}{l}\text { Killing of another } \\
\text { female to get drugs }\end{array}$ \\
\hline
\end{tabular}

they are female", the action is seen as leading to acts that are intended to bring grave consequences to the female victims.

The third and final category, "Female Acting on Own Behalf", represents women's own crimes against themselves. These include mass killing by women out of jealousy towards other women, greed (in cases of property inheritance) and other issues that are related. These form the basis for a 
femicide reading of the two texts, Perawan Remaja dalam Cengkeraman Militer (2001) and Cantik itu Luka (2004).

\section{BACKGROUND OF THE NOVELS PERAWAN REMAJA DALAM CENGKERAMAN MILITER (2001) AND CANTIK ITU LUKA (2004)}

Perawan Remaja dalam Cengkeraman Militer is a novel by Pramoedya Ananta Toer published in 2001. Generally, the novel is about a teenage Indonesian girl who was made a sex slave by the Japanese army during the Second World War. The text records the author's experiences, testimonies by fellow exiles on Pulau Buru, as well as their conversations about the victims who were left behind on the island after the Japanese surrender in 1945. The irony about this work is that in 2001, the same year that the book was published in which Pramoedya revealed the atrocities commited by Japanese troops, the Japanese government invited him to receive the Asia Fukuoka Cultural Prize in honour of his outstanding contribution towards the preservation of Asian culture.

The Second World War caused disruptions in maritime and air communications, which made it difficult for the Dai Nippon (Imperial Japanese) army to bring over female companions from Japan, China and Korea. This situation was the cause for the existence of jugun ianfu or "comfort women" in Indonesia. At first, these women were promised the chance to study in Tokyo or Shonanto (Singapore) to become nurses, teachers and clerks. Girls began to leave their hometowns and families not of their own free will but because of their parents who were afraid of Japanese threats. They had to undergo a long and dangerous journey in the midst of wartime activities.

Adolescent girls were chosen for several reasons, among them the parents' fear of Japanese cruelty, which sometimes resulted in the parents becoming moles acting for the Japanese, hence they had to comply with their demands. The main draw was the Japanese government's promise to employ the girls as workers. The girls' fortunes worsened when the Japanese surrendered in 1945 and they were left to fend for themselves without any compensation or protection. Among the characters portrayed in the novel are Siti F, Suwarti, Kartini and Sumiyati. They have prevailed and become a part of Pulu Buru's community, although they have become outcasts and 
lead lives on a much lower status than previously. They may even have been forgotten or considered as non-existant, or to have vanished.

They were afraid to speak in their mother tongue or talk about themselves to others in the company of their husbands or the inhabitants of Buru. They were imprisoned within the limited sphere of their own lives. The difficult conditions of their lives made them age quicker. As expected, many of the other women died, especially because there was no medical aid and there were unchecked outbreaks of epidemics.

Pramoedya wrote many of novels on the theme of war. The novel Perawan Remaja dalam Cengkeraman Militer (2001) was written when he was imprisoned on Pulau Buru, an island known as the place where political detainees are exiled. Pramoedya wrote about the Indonesian girls who were forced to become sex slaves during the war with the Japanese. They unburdened their secrets which they had carried for decades to Pramoedya, making him their shoulder to cry on. The arrival of Pramoedya was like a light at the end of the tunnel for them.

Meanwhile, the novel Cantik Itu Luka (2004) describes the atmosphere during the Dutch and Japanese colonial period in Indonesia. Dewi Ayu is a Dutch girl renowned for her beauty but also the most hated in the village. During the Japanese occupation, the Japanese force Dewi Ayu to become a prostitute placed in the brothel of Mama Kalong. She gives birth to three beautiful daughters: Alamanda, Adinda and Maya Dewi. Even when, upon the arrival of the Japanese, the Dutch families are asked to return to their place of origin, Dewi Ayu does not do so.

Because of her beauty, Dewi Ayu is sought after by men. Due to the circumstances of her life, she has to live life as a prostitute at Mama Kalong's brothel, working to fulfil the sexual appetite of Japanese soldiers. Her children do not know who their biological fathers are. She experiences her greatest regret when her daughters follow in her footsteps and use their beauty to become prostitutes themselves.

Dewi Ayu's eldest daughter Alamanda is forced to marry a Japanese man named Shodancho. Her second daughter Adinda marries a man called Comrade Kliwon and together they have a child named Krisan. Dewi Ayu's third daughter is married off at the age of 12 to a man called Maman Gendeng.

The novel then flashes back to the time before the war when Dewi Ayu was a child, during the era of Dutch colonial rule - a world filled with parties at tennis courts, obedient servants, noisy residences as well as luxuryà la 
Buitenzorg, before coming to an end due to the Japanese invasion, life in detention camps, violence and the prostitution of women by the military.

\section{A FEMICIDE READING OF THE RESEARCH TEXTS}

In this section, the discussion will apply a femicide reading, as introduced by Russell, to prove that women become gender victims of men in the two novels, Perawan Remaja dalam Cengkeraman Militer (2001) and Cantik Itu Luka (2004). One category of war crimes that can be most closely related to war in the context of Russell's femicide reading, proposed in her research entitled Femicide in Global Perspective, is that of females acting as agents of crime on behalf of men. This crime is also known as social femicide, which includes "woman-killing, such as women being permitted to die because of misogynist and/or social institutions" (2001, p. 18).

\section{Application of "Females Acting as Agents of Male Perpetrators"}

In a femicide reading of both novels, one of the categories of the characteristics of war crime that can be applied to these works is "females acting as agents of male perpetrators". Under this category, the womenfolk become victims of male brutality, as they are subjected to injury and death. In this situation, Russell explains, abuse or murder of women can be seen as a direct or an intentional act. She goes on to say:

However, their use of the term intentional is problematic since nonintentional killings of women can also be instances of femicide. For example, a battering husband may not have intended to kill his wife when he attacked her, but his unintentional act would certainly qualify as femicide by my definition.

(2001, p. 15)

Looking at the context of the novel Perawan Remaja dalam Cengkeraman Militer (2001), the abuse of women by men can be identified in several situations. Firstly, women, or more precisely those who were forced to become comfort women, were manipulated using promises made by the Japanese military that was ruling Indonesia at that time, in order for them to bring young girls to secret locations. This was the beginning of their 
endless suffering. Like Kartini, these girls were raped. Pramoedya narrates the unfortunate event (2001, p.62):

Sahaya dibawa masuk ke dalam kamar kapal. Pelangi itu juga yang jadi penutup muka sahaya. Ia geletekkan sahaya... dan waktu terbangun seluruh badan lemas, pakaian rusak semua... badan sakit semua. Ya, Nak, terang-terangan saja, Ibu sudah tua sekarang, apa pula guna malu. Sipen na (kemaluan ini) bengkak. Sahaya menangis. Tapi tiap sahaya menangis dia malah datang lagi dan diulanginya perbuatannya... dan sahaya pingsan lagi. Begitu terus sampai sahaya tak dapat menangis lagi.

[I was brought into a room on the ship. The rainbow hid my face. He tickled me... and when I got up my whole body was numb, my clothes torn, my whole body aching. Yes, Son, I am old now, there's no point in being embarrassed. My vagina was swollen. I cried. But every time I cried, he would come back and repeat what he did... and I would faint again. It went on that way until I couldn't cry any longer.]

The situation only worsens when, after the defeat of the Japanese in 1945 , the suffering of the victims does not end. Some of them who were deported to Buru Island had to undergo further suffering. This is because men dominated the women's lives, as portrayed by the character Sumiyati in the novel. Sumiyati lives a miserable life under the norms of the Alfuru community, who considers women as their husbands' property. The author describes it as follows (2001, p. 62):

Para suami Alfuru itu takut istrinya meninggalkan Buru dan kembali ke Jawa. Ketakutan ini didasarkan atas pendangan adat setempat bahawa istri adalah harta bagi suami, sama dengan harta lainnya yang bias dipertukarkan, dijual, diwariskan kepada adik atau bapa, dan lebih parah lagi: menjadi sumber tenaga dan penghidupan bagi suami.

[The Alfuru husbands feared that their wives would leave Buru and return to Java. This fear was based on the local custom that a wife is the property of the husband, the same as any other property he owns: to be exchanged, sold, passed on to his brother or father and, worse still, as the source of energy and livelihood for the husband.] 
This situation forces the women to obey their husbands' wishes in everything, although it goes against the right to freedom that should be enjoyed by women even after they are married. It is a situation that is consistent with Russell's explanation of "gang members who participate or assist male members in femicides of female gang members and/or other females" (1992, p. 14).

Apart from this, Sri Sulastri from Semarang unashamedly tells Pramoedya and friends how she longs to return to her birthplace on Java. Sri Sulastri fervently pleads (2001, pp. 49-51):

"Suami saya tidak pernah membiarkan saya berbicara dengan orang lain semacam ini. Apalagi kalau diketahuinya saya menggunakan bahasa yang ia tidak paham. Ia terlalu mencurigai saya. Apalagi setelah banyak orang dari Jawa datang kemari. Keadaan ini semakim menyempitkan ruang gerak saya. Karena itu saya mengharap, kalau nanti pulang ke Jawa bawalah saya."

["My husband would never allow me to talk to other people in this way. It's worse if he finds out that I have spoken in a language that he doesn't understand. He's very suspicious of me. Now it's even worse with more people from Java coming over here. This makes it even more difficult for me to move about. Thus, I plead, when you go back to Java, please take me with you"]

The experience of being raped and then becoming a victim of injustice in marriage on Buru Island is not a moral burden but leaves tragic emotional scars on all the victims. These unfortunate and ill-treated women can only groan and cry, on a pleading note, as described by Pramoedya (2001, p. 39).

"Mereka semua ingin pulang. Tak ada fasilitas. Tak ada uang. Tak ada pelindung. Tak ada kenalan. Di luar negeri. Tetapi banyak juga, walaupun ingin pulang, merasa menanggung beban moral yang berat, merasa telah tercemar, dan tak sampai hati mencemari nama keluarga.

Juga Sumiyati ingin pulang. Tentu saja. Tetapi sekarang ia sudah bersuami, maka ia merasa kemungkinan untuk itu menjadi lebih tipis lagi. apalagi, katanya pada saya, "Saya sudah ternoda begini. Saya sudah punya suami. Lebih baik saya membantu perjuangan kemerdekaan Indonesia dari jauh, meski pun tidak banyak." 
["All of them wanted to go home. There were no facilities. No money. No protection. No acquaintances. They were exiles. But there were still many who were carrying a heavy moral burden and felt so defiled they did not want to embarrass their family, although they wanted to go home.

Sumiyati wanted to go home. Certainly. But now she had a husband, hence the likelihood of going home seemed even farther away. She said to me further, "I am already defiled. I have a husband. It's better that I help towards achieving Indonesian independence from far, although in a small way."]

These are the consequences of war that the women had to bear involuntarily. They were not only victims of rape during wartime, they also had to bear the post-war implications, without any protection or support. The wartime rapes described in both novels can also be viewed in the context of the patriarchal system that underlies governmental authority shaped the political, economic, cultural and hierarchal structure of society. Based on the rapes described in the novels, it is clear that there were groups of women who became sex slaves and were abused by men. Therefore, Sumiyati, Kartini and Sri Sulastri are vulnerable characters who, as victims of the Japanese army and the Alfuru community, serve as examples of cases in which "females [act]as agents of male perpetrators".

Meanwhile, in the novel Cantik Itu Luka (2004), the writer demonstrates the characteristics of "females acting as agents of male perpetrators", in several situations portrayed in the novel. Eka Kurniawan depicts abuse by men, both as perpetrated by Dutch soldiers or attitudes within families in the postcolonial society. The situation of 1965 is manifested in an imaginary city called Halimunda, a city filled with people of various social classes and religions, and belief systems. The author not only creates a fictional scenario but also revisits a history scarred by the war. The Japanese army occupying the country carries on having comfort women, not only from among the local populace but also among the Dutch women.

This novel introduces the character of Dewi Ayu, the daughter of a Dutch father and his local mistress, who ends up becoming a prostitute. She continues life as a prostitute and goes on to have three beautiful daughters. When Dewi Ayu falls pregnant with her fourth child, she hopes that the child would be ugly, and it turns out to be so. She names this daughter $\mathrm{Si}$ Cantik (Beauty). 
In a situation such as this, the most unfortunate are the local girls who have to offer themselves up to the Japanese and the Dutch. This situation gives of "females acting as agents of male perpetrators", whereby in the first incident, Pak Tua sells his daughter Rosinah as payment for Dewi Ayu's services, as elaborated on in the citation below:

"Kau bisa jadikan ia pelacur dan ambil uangnya seumur hidup," kata lelaki tua itu. "Bahkan jika tak ada lelaki yang mau dengannya, kau bisa mencincangnya dan menjual dagingnya di pasar."

["You can make her a prostitute and take her money for the rest of her life," the old man said. "In fact, if no man wants her, you can cut her up and sell her flesh at the market."]

The cruelty of the army of Indonesia's former colonial masters, the Dutch, is also shown in this novel when the soldier rape young Indonesian girls. The character Ma Iyang, who was a victim, appears to be devoid of all emotion as she feels that men's lust is meaningless. She says:

“Apakah kau masih mengharapkanku?" tanya Ma Iyang. "Seluruh tubuhku telah dijilati dan dilumuri ludah orang Belanda, dan kemaluanku telah ditusuk kemaluannya sebanyak seribu seratus sembilan puluh dua kali."

["Are you still hoping for me?" asks Mak Iyang. "Dutch spit has licked and smeared my whole body and my private part has been pierced by theirs a thousand one hundred and ninety two times."]

(2003, p. 34)

At the same time, the novel clearly exposes the rape and abuse of girls from Dutch families taken captive by Japanese soldiers.

Jumlahnya lebih dari sepuluh orang, dan kini mereka mengumpulkan semua tawanan tersebut. ketika diketahui seтua perempuan dan semua orang-orang Belanda, mereka bertambah beringas. Beberapa di antara mereka diikat di dapur dan sebagian lagi diseret ke kamar tidur untuk diperkosa. Teriakan-teriakan mereka jauh lebih memilukan daripada ketika orang-orang Jepang menjadikan mereka 


\section{MALAY LITERATURE VOLUME 33 NUMBER 1 JUNE 2020}

pelacur, dan bahkan Dewi Ayu harus berkelahi terlebih dahulu dengan seorang gerilyawan yang merampas bayi dan melukai tangannya dengan pisau.

Kemudian tentera-tentera itu mulai mengambil gadis-gadis tersebut satu per satu, dalam satu perkelaian yang dengan mudah mereka menangkan. Mereka membawa gadis-gadis itu ke dalam jepitan tangan, bagaikan membawa kucing sakit, dan mereka meronta-ronta penuh dengan kesia-siaan.

[The total number was more than 10 , and they gathered all the detainees. When they discovered that all were girls and all were Dutch they became even more aroused. Some of the girls were tied up in the kitchen and some were dragged to the bedrooms to be raped. Their screams were far more pitiful than when they had been made prostitutes of the Japanese, in fact Dewi Ayu first had to fight with a guerilla who snatched a baby and wounded her with a knife.

Then, these soldiers started to take the girls one by one, in a struggle which they easily won. They dragged the girls in their grip, like carrying a sick cat, and the girls would struggle in vain.]

(2004: 96)

Some of them were the same people who killed several Dutch soldiers and they raped Dewi Ayu and her friends before the British came and saved the girls. Eka Kurniawan described the harrowing incidents as follows:

(1)The Rape of Alamanda by Shodancho

Alamanda tak hanya ingin melolong, ia bahkan ingin mencekik lehernya sendiri agar mati sebelum laki-laki di depannya berbuat lebih jauh dari itu.

Sang Shodancho tiba-tiba menangkap tubuhnya dari belakang, menarik pakaian tidur istrinya begitu kuat hingga sobek terkoyak dan menanggalkannya.

[Alamanda wanted to do more than scream, in fact she wanted to strangle herself before the man in front of her did more than that. 
Shodancho suddenly grabbed her from behind, wrenched at her nightdress with such force that it ripped to shreds, and then he took it off.]

(2004, p. 225)

Kedua tangan dan kedua kakinya terikat ke empat sudut tempat tidur. alamanda mencoba bangun dan menarik tali pengikat, namun rupanya ikatan itu begitu kencang sehingga apa yang terjadi hanya membuat pergelangan tangan maupun kakinya terasa sakit.

[Both her hands and legs were tied to the four corners of the bed. Alamanda tried to get up and pull at the cords, but the knots were so tight that they merely bruised her wrists and legs.]

(2004, p. 227)

(2) Krisan's Cruelty towards Rengganis

Selama sembilan bulan Krisan diteror rasa takut bahwa orang. Terutamanya Maman Gendeng dan Maya Dewi, dan juga ibunya, tahu bahawa Krisanlah yang menyetubuhi Rengganis Si Cantik. Ia merencanakan membunuh gadis itu di gubuk gerilya, untuk mengubur semua cerita tersebut, tapi kemudian ia membunuhnya di atas perahu, dan membuang mayatnya ke laut.

[For nine months Krisan feared that people, especially Maman Gendeng and Maya Dewi, and her mother, would know that Krisan was the one who had slept with Rengganis Si Cantik. He planned to kill the girl in his guerilla's cabin to cover up the story but he later killed her on the boat and threw her corpse into the sea.]

Based on these excerpts, it is very clear that the war brought about much suffering to these Indonesian girls, whose stories were fictionalized. However, what is important is, these girls are a part of history, victims of power shifts and the bitterness of a society that no longer subscribed to humanitarian values.

Another category in a femicide reading is that of "females acting on their own behalf", which can observed in the novel Cantik Itu Luka (2004). This situation is depicted through Dewi Ayu's sacrifice, not out of jealousy of her beautiful daughters but to save her sick children. She sleeps with 
a Japanese commandant at the detention camp to obtain medicine for her sick children.

It is fitting, therefore, for Pramoedya, in writing the novel Perawan Remaja dalam Cengkeraman Militer to remind Indonesian girls that they should remember the sacrifices made by their foremothers who were illtreated, who had to undergo bodily and emotional changes. Eka Kurniawan reminds his readers that cantik itu luka means that beauty can be a source of suffering. Therefore the application of a femicide reading method on the discussion of these two novels not only details the rape and murder of women by men during wartime but the findings of the analysis also show that war brings suffering, sorrow, destruction, damage, separation and enmity without end. What is certain, war does not bring any sense of happiness.

\section{CONCLUSION}

To conclude, the creation of jugun ianfu or "comfort women" is a war crime that should be given serious attention, considering that the effects are felt up to this day, especially by the forgotten victims of war and their families. The actions of the military, who made helpless women mere tools to satisfy their lust are inhumane and apparently were intentional acts committed to challenge the rules of war which should not involve children, women, and the elderly. More than that, it reveals that this really happened in Indonesia during the war, to women who were not able to defend themselves. They had to submit to the Japanese soldiers who implemented their own laws in these occupied lands.

Today, more than 75 years after the emergence of "comfort women", no appropriate steps to rectify this injustice have been taken by the Japanese government; it has maintained its silence although there are efforts by the victims to seek justice. Therefore, the writing of these novels by Pramodeya Ananta Toer and Eka Kurniawan may be able to let the international community know and understand the tragic history of "comfort women" during the Japanese occupation, especially in Indonesia.

The discussion to reveal the fate of women as a result of war through a femicide reading, proposed by Russell as basically being "the killing of females by the males because they are female", explains the occurrence of gender-based murder by men in various ways. These incidents occurred in many places in the occupied territories and women became victims of war. The issue of females becoming victims of war in this way is not an isolated 
one. The crime of rape is especially rampant during wartime around the world, and the effects of the trauma continue long after the war has ended.

\section{REFERENCES}

Argibay, Carmen M. (2003). Sexual Slavery and the "Comfort Women of World War II. Berkeley Journal of International Law, 21, 375-389.

Chaudhury, Sabyasachi Basu Ray and Samaddar, Ranabir. (2018). The Rohingya in South Asia: People Without a State. New York: Routledge.

Eka Kurniawan. (2004). Cantik Itu Luka. Jakarta: Penerbit PT Gramedia Pustaka Utama.

Esguerra, George F. (2012). The Borough of Licab. New York: Trafford Publishing. Greenlees, Donald. (2005). "Occupation Helped Put Indonesia on the Path to Independence". Retrieved from https://www.nytimes.com/2005/08/15/ world/asia/occupation-helpedput-indonesia-on-the-path-to-independence. html.

Hassan, Ghali. (2004). Colonial Violence against Women in Iraq 31 May, 2004. Retrieved from http://www.countercurrents.org/iraq-hassan310504. htm.

Huie, S. Fenton. (1992). The Forgotten Ones: Women and Children under Nippon. NSW, Australia: Angus and Robertson.

Hicks, George. 1995. The Comfort Women: Sex Slaves of the Japanese Imperial Forces. Singapore: Heinemann Asia.

Impact of War World II. Retrieved from https://courses.lumenlearning.com/ boundlessworldhistory/chapter/impact-of-war-world-ii/

Kumagai, Naoko (trans. David Noble). (2016). The Comfort Women: Historical, Political, Legal and Moral Perspectives. Tokyo: International House of Japan.

Mark, Ethan. (2018). Japan's Occupation of Java in the Second World War: A Transnational History. London: Bloomsbury Publishing.

Post, P., Frederick, W. H., Heidebrink, I. et al. (2010). The Encyclopedia of Indonesia in the Pacific War: In cooperation with the Netherlands Institute for War Documentation. Leiden: Brill.

Pramoedya Ananta Toer. (2001). Perawan Remaja dalam Cengkeraman Militer. Jakarta: Kepustakaan Populer Gramedia.

Russell, Diana E. H. and Harmes, Roberta A. (2001). Femicide in Global Perspective. New York:Teachers College Press.

Skidmore, Monique. (2003). Behind Bamboo Fences: Forms of Violence Against Women in Myanmar. Violence Against Women in Asian Societies. London: Routledge. 
MALAY LITERATURE VOLUME 33 NUMBER 1 JUNE 2020

Swee Lian. (2008). Tears of a Teen-Age Comfort Woman. Singapore: Horizon Books.

Understanding and Addressing Violence Against Women-Femicide. (2012. Retrieved from http://apps.who.int/iris/bitstream/handle/10665/77421/ WHO_RHR_12.38_eng.

Received: 27 July 2019

Accepted: 6 April 2020 